\title{
p53 protein expression in non-Hodgkin's lymphoma. Comparative study with the wild type p53 induced proteins $\mathrm{mdm} 2$ and p21/waf1
}

Department of

Pathology, University Hospital of Heraklion, Heraklion

M Tzardi

Ch Kouvidou

I Panayiotides

K Stefanaki

K Koutsoubi

G Delides

P Kanavaros

Department of

Pathology,

Evagelismos Hospital

of Athens, Athens

D Rontogianni

Department of

Pathology, Venizelion

Hospital of Heraklion,

Heraklion

E Zois

\section{Department of \\ Haematology, \\ University Hospital of \\ Heraklion, Heraklion \\ G Eliopoulos}

Correspondence to:

Dr P Kanavaros, University of Crete, Faculty of

Medicine, 1393 Heraklion,

Crete, Greece.

Accepted for publication 9 July 1996

M Tzardi, Ch Kouvidou, I Panayiotides, K Stefanaki, D Rontogianni, E Zois, K Koutsoubi, G Eliopoulos, G Delides, P Kanavaros

\begin{abstract}
Aims-To investigate the pattern of expression of p53 protein and two wild type p53 induced proteins ( $\mathrm{mdm} 2$ and p21/ waf1) as an indirect way of assessing p53 gene status in non-Hodgkin's lymphoma. Methods-Formalin fixed, paraffin wax embedded tissue from 87 cases of nodal non-Hodgkin's lymphoma, comprising 52 high grade and 35 low grade tumours, was stained by immunohistochemistry for p53, mdm2 and p21/wafl proteins.
\end{abstract}

Results-p53, mdm2 and waf1/p21 proteins were expressed in $36 / 52,21 / 52$ and $31 / 52$ high grade and $3 / 35,21 / 35$ and $3 / 35$ low grade non-Hodgkin's lymphomas, respectively. Parallel p53/mdm2 protein expression was found in 23 cases ( 21 high grade and two low grade). These 23 cases were also positive for p21/waf1 protein expression. Discordant p53 positive/ mdm2 negative protein expression was found in 16 cases (15 high grade and one low grade). Eleven (10 high grade and one low grade) of these 16 cases were p21/waf1 positive and the remaining five high grade non-Hodgkin's lymphomas were p21/wafl negative. Mdm2 and p21/waf1 proteins were not expressed in the absence of p53 protein expression.

Conclusions-p53, mdm2 and waf1/p21 protein expression is more frequently associated with aggressive histotypes of non-Hodgkin's lymphoma. Parallel expression of $\mathrm{p} 53, \mathrm{mdm} 2$ and $\mathrm{p} 21$ proteins may represent non-Hodgkin's lymphomas with a wild type p53 gene as mdm2 and p21 proteins can be induced by the wild type gene. In these cases $p 53$ protein expression may result from stabilisation via complex formation with the mdm2 protein. This could be important in the pathogenesis of these cases as mdm2 may deregulate the p53 dependent growth suppressive pathway. Discordant p53 positive/mdm2 negative/p21 negative protein expression may represent non-Hodgkin's lymphoma with p53 gene mutations unable to activate expression of $\mathrm{mdm} 2$ and $\mathrm{p} 21$ proteins. Non-Hodgkin's lymphoma with p53 positive/mdm2 negative/p21 positive protein expression may have either wild type p53 with deregulated mdm 2 gene expres- sion or mutated p53 gene with p53 independent p21 expression.

(f Clin Pathol: Mol Pathol 1996;49:M278-M282)

Keywords: non-Hodgkin's lymphoma, p53, mdm2, p21.

p53 gene mutations are the most frequent genetic alterations found in human tumours. ${ }^{1-4}$ p53 protein expression either secondary to p53 gene mutation or because of adhesion to other cellular or viral proteins can be detected by immunohistochemistry. ${ }^{45}$ An indirect way to analyse p53 gene status is by the investigation of protein expression induced by wild type $\mathrm{p} 53$. One of these is the mdm 2 protein, which forms a complex with p53 thereby inhibiting p53 function. ${ }^{6-9}$ Wild type p53 induces mdm2 transcription via a p53 responsive element in the first intron of the mdm2 gene. ${ }^{10}{ }^{11} \mathrm{p} 53$ and $\mathrm{mdm} 2$ proteins interact with each other, forming a self-regulating feedback loop. ${ }^{112} \mathrm{p} 21 /$ wafl protein is a wild type p53 inducible protein which inactivates the cyclin/cyclin dependent kinase (CDK) complexes, blocking cell cycle progression at the $G_{1}$ to $S$ interface. ${ }^{13-16}$ There is evidence that $\mathrm{p} 53$, after DNA 'damage', increases the expression of p21 protein, which binds to cyclin/CDK complexes resulting in inhibition of retinoblastoma (Rb) protein phosphorylation. ${ }^{13-16}$ In addition, p21/waf1 protein blocks the action of proliferating cell nuclear antigen (PCNA), impeding DNA replication. ${ }^{17}$ In tumour cells that have either lost p53 protein or contain an altered form of $\mathrm{p} 53, \mathrm{p} 21$ concentrations are dramatically reduced or the protein is absent. ${ }^{13}{ }^{15}$ This could result in abnormal control of DNA replication or loss of coordination between DNA replication and the cell cycle. ${ }^{17}$ Both could lead to genomic instability which is directly related to oncogenesis.

Previous investigations on non-Hodgkin's lymphomas, showed that p53 protein expression is a frequent finding in the high grade variant. $^{451819}$ p53 protein expression in nonHodgkin's lymphoma is sometimes secondary to p53 gene mutations, but in many cases is independent of mutation. ${ }^{45-20}$ In addition, $\mathrm{mdm} 2$ protein has been detected in a proportion of high grade non-Hodgkin's lymphomas, but less frequently than p53 protein. ${ }^{20}$ Prompted by these data, we investigated, using 
immunohistochemistry, the expression of $\mathrm{p} 53$, $\mathrm{mdm} 2$ and $\mathrm{p} 21 / \mathrm{waf} 1$ in a series of 87 cases of nodal non-Hodgkin's lymphoma, to obtain indirect information about the status of p53 gene in these tumours.

\section{Methods}

All 87 cases of nodal non-Hodgkin's lymphoma were retrieved from the archives of the Departments of Pathology, University Hospital and Venizelion Hospital of Heraklion, Greece. These were classified according to the updated Kiel classification (1988) into 52 high grade (47 B non-Hodgkin's lymphomas and five T non-Hodgkin's lymphomas) and 35 low grade (32 B non-Hodgkin's lymphomas and three T non-Hodgkin's lymphomas) tumours. The material comprised 18 follicular centroblastic/ centrocytic B non-Hodgkin's lymphomas, three centrocytic (mantle cell) B nonHodgkin's lymphomas, nine immunocytomas, two lymphocytic B non-Hodgkin's lymphomas, three angioimmunoblastic lymphadenopathy $T$ non-Hodgkin's lymphomas, four immunoblastic B non-Hodgkin's lymphomas, 39 centroblastic B non-Hodgkin's lymphomas, two Burkitt-type B non-Hodgkin's lymphomas, three pleomorphic medium and large cell

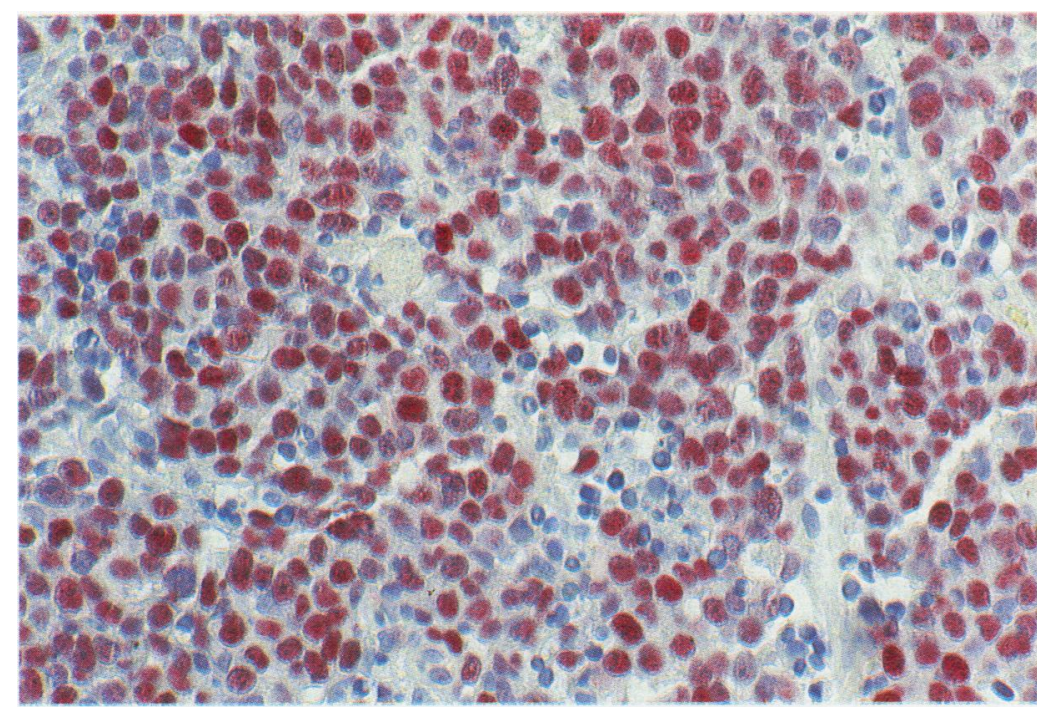

Figure 1 p53 protein expression in a high grade non-Hodgkin's lymphoma.

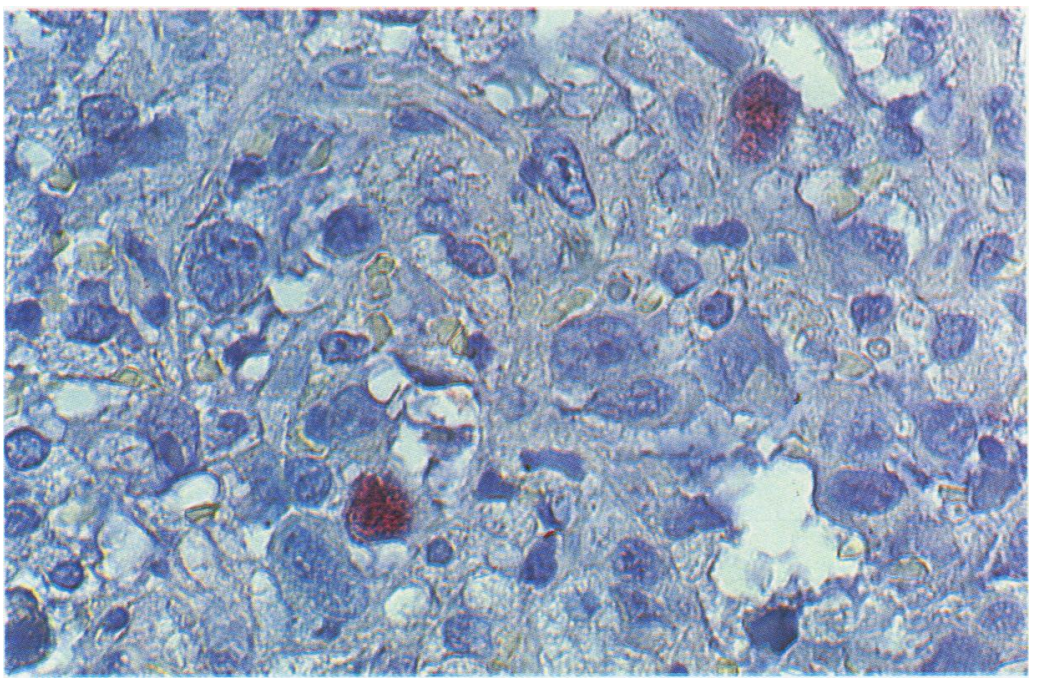

Figure $2 M d m 2$ protein expression in a high grade non-Hodgkin's lymphoma.
Table 1 Expression of $p 53, m d m 2$ and $p 21 /$ waf 1 proteins in non-Hodgkin's lymphoma. Results are expressed as number positive/total number

\begin{tabular}{llll}
\hline $\begin{array}{l}\text { Non-Hodgkin's } \\
\text { lymphoma }\end{array}$ & $p 53$ & $m d m 2$ & $p 21 /$ waf1 \\
\hline High grade & $36 / 52$ & $21 / 52$ & $31 / 52$ \\
Low grade & $3 / 35$ & $2 / 35$ & $3 / 35$ \\
Total & $39 / 87$ & $23 / 87$ & $34 / 87$ \\
\hline
\end{tabular}

T non-Hodgkin's lymphomas, two anaplastic large cell B non-Hodgkin's lymphomas, and two anaplastic large cell T non-Hodgkin's lymphomas. Four reactive lymph nodes were also included as controls.

IMMUNOHISTOCHEMISTRY

Immunostaining was performed on formalin fixed, paraffin wax embedded tissue sections using the alkaline phosphatase-anti-alkaline phosphatase (APAAP) method. ${ }^{21}$ Monoclonal antibodies directed against mdm2 (Oncogene Sciences), p53 (D07: Dako, Glostrup, Denmark) and p21/waf1 (Oncogene Sciences) were applied at a dilution of 1 in 100 for three hours. The bridging rabbit antimouse ( $Z$ 259) and APAAP complexes (D 314) were obtained from Dako. All sections were heated in citrate buffer in a microwave oven prior to incubation with all antibodies, as described previously. ${ }^{22}$ Positive control slides were included in all tests and consisted of paraffin wax sections from a patient with Hodgkin's disease known to be positive for $\mathrm{p} 53$, mdm 2 and $\mathrm{p} 21 /$ waf1 proteins. Negative control slides were prepared by omitting the primary antibody. In all cases the quality of antigenic preservation was tested by immunostaining for PCNA (Oncogene Sciences).

\section{Results}

IMMUNOHISTOCHEMISTRY

The results are summarised in table 1.

p53 PROTEIN EXPRESSION

p53 nuclear staining was found in 39/87 cases of non-Hodgkin's lymphoma. In correlating p53 expression with histological type, positive staining was observed in three of 35 low grade and in 36/52 high grade non-Hodgkin's lymphomas. p53 positive cells represented $1-5 \%, 5-25 \%, 25-50 \%$, and $>50 \%$ of lymphoid cells in 28, five, four, and two cases, respectively (fig 1). The three low grade non-Hodgkin's lymphomas exhibited p53 nuclear staining in $1-5 \%$ of tumour cells. Rare p53 positive cells were found in germinal centres and in interfollicular areas in all reactive lymph nodes.

MDM2 PROTEIN EXPRESSION

Mdm2 nuclear staining was found in $23 / 87$ cases of non-Hodgkin's lymphoma (21/52 high grade and two of 35 low grade). Mdm2 positive cells represented $1-5 \%$ of the lymphoid cells in all but four high grade nonHodgkin's lymphomas with $5-25 \%$ positive cells and one high grade non-Hodgkin's lymphoma with $25-50 \%$ positive cells (fig 2). Rare mdm 2 positive cells were found in germi- 


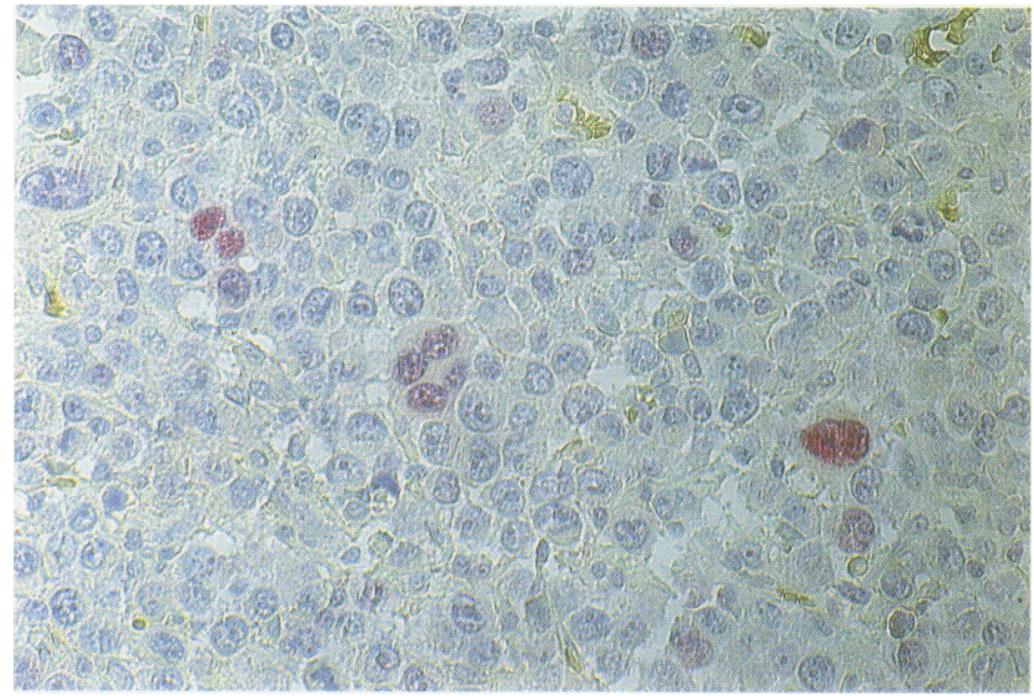

Figure 3 p21/waf1 protein expression in a high grade non-Hodgkin's lymphoma.

nal centres and in interfollicular areas in all reactive lymph nodes.

\section{p21/WAF1 PROTEIN EXPRESSION}

p21 nuclear staining was found in 34/87 cases of non-Hodgkin's lymphoma (31/52 high grade and three of 35 low grade). p21 positive cells represented $1-5 \%$ of the lymphoid cells in all but six high grade non-Hodgkin's lymphomas with $5-25 \%$ positive tumour cells (fig 3). Rare p21 positive cells were found in germinal centres and in interfollicular areas in all reactive lymph nodes.

RELATIONS BETWEEN EXPRESSION OF p53, MDM2 AND $\mathrm{p} 21$

Parallel p53/mdm2 expression was found in 23/87 cases of non-Hodgkin's lymphoma (21 high grade and two low grade) (table 2). All 23 cases were also p21/waf1 positive. Discordant p53 positive/mdm2 negative expression was found in 16/87 cases (15 high grade and one low grade). Eleven of these 16 cases (10 high grade and one low grade) were $\mathrm{p} 21 /$ waf1 positive and the remaining five high grade nonHodgkin's lymphomas were p21/waf1 negative. $\mathrm{Mdm} 2$ and $\mathrm{p} 21 /$ waf1 proteins were not expressed in the absence of p53 protein expression.

\section{Discussion}

p53 protein expression can be a consequence of p53 mutation, which stabilises the protein, or it could depend on other factors, such as association with other viral or cellular proteins. ${ }^{14518-20}$ An indirect way of assessing p53 gene status is by the investigation of the expression of $\mathrm{mdm} 2$ and $\mathrm{p} 21 /$ waf1 proteins. Wild type p53 is able to upregulate wafl gene transcription, resulting in an enhanced expression of $\mathrm{p} 21$ protein. ${ }^{1314}$ This protein mediates

Table 2 Patterns of $p 53, m d m 2$ and $p 21 /$ waf1 protein expression

\begin{tabular}{lll}
\hline Pattern of expression & Number of cases & Histotype \\
\hline p53+/mdm2+/p21+ & 23 & 21 High grade, 2 low grade \\
p53+/mdm2+/p21- & 0 & 10 High grade, 1 low grade \\
p53+/mdm2-/p21+ & 11 & All high grade \\
p53+/mdm2-/p21- & 5 & \\
\hline
\end{tabular}

cell cycle arrest by inhibiting the formation of cyclin/CDK complexes. ${ }^{13-16}$ Wild type p53 also induces transcription of the mdm2 gene. $^{1011}$ This gene, localised at 12q13-14, when amplified or overexpressed, or both, may increase the capacity of the cell to undergo tumorigenesis. The mdm2 gene has been found to be amplified in human sarcomas ${ }^{23}$ and gliomas, ${ }^{24}$ and is overexpressed in breast cancer, Hodgkin's disease, acute leukaemias, chronic lymphocytic leukaemias, and B cell lymphomas. ${ }^{25-28}$ It encodes a nuclear protein, which can bind p53, inhibiting p53 transcriptional control by concealing its transactivational domain. $^{8}$

Prompted by these data we investigated p53, $\mathrm{mdm} 2$ and $\mathrm{p} 21 / \mathrm{waf} 1$ protein expression in non-Hodgkin's lymphoma. We found the expression of these three proteins was more frequently associated with high grade nonHodgkin's lymphoma. These proteins were rarely found in the low grade variant. Our results for $\mathrm{p} 53$ and $\mathrm{mdm} 2$ are in keeping with previous findings ${ }^{4518}{ }^{2029-31}$ and indicate that $\mathrm{p} 53, \mathrm{mdm} 2$ and $\mathrm{p} 21 / \mathrm{waf} 1$ protein expression is associated with aggressive histological types of non-Hodgkin's lymphoma.

Two patterns of $\mathrm{p} 53 / \mathrm{mdm} 2$ protein expression were found in non-Hodgkin's lymphoma. (1) Simultaneous $\mathrm{p} 53 / \mathrm{mdm} 2$ protein expression in 23 cases of non-Hodgkin's lymphoma (21 high grade and two low grade). All of these cases were also p21/waf1 positive. There is evidence that $\mathrm{mdm} 2$ protein is present mainly in cases with wild type p53. ${ }^{24-28}$ In addition, p21/waf1 protein expression is induced by the wild type p53 gene. ${ }^{13}$ Thus, the detection of $\mathrm{mdm} 2$ and $\mathrm{p} 21 / \mathrm{waf} 1$ proteins in these cases of non-Hodgkin's lymphoma suggests that the p53 gene is not mutated and that $\mathrm{mdm} 2$ expression could be one of the factors leading to stabilisation of the $\mathrm{p} 53$ protein. This observation is supported by previous findings that of 17 cases of non-Hodgkin's lymphoma with $\mathrm{mdm} 2$ gene overexpression, 14 had a wild type p53 gene. ${ }^{27}$ This could be of interest with regard to the pathogenesis of the $\mathrm{p} 53$ positive/ $\mathrm{mdm} 2$ positive cases. As $\mathrm{mdm} 2$ can inhibit $\mathrm{p} 53$ mediated transactivation, ${ }^{7-9}$ it is possible that $\mathrm{mdm} 2$ expression may be involved in the pathogenesis of some, predominantly high grade non-Hodgkin's lymphomas, by deregulating the p53 dependent growth suppressive pathway. Previous studies have investigated the molecular mechanisms of mdm2 gene deregulation in lymphoid neoplasms. ${ }^{262730}$ By Southern blotting, in only one case of follicular B non-Hodgkin's lymphoma ${ }^{30}$ of a total of 162 cases of non-Hodgkin's lymphoma and lymphoid leukemias tested was mdm 2 gene amplification detected. ${ }^{262731}$ This suggests that mechanisms other than gene amplification, possibly mdm2 gene overexpression ${ }^{26}$ or enhanced translation, ${ }^{32}$ may play a role in deregulating mdm 2 gene expression in nonHodgkin's lymphomas and lymphoid leukaemias.

(2) p53 protein expression without $\mathrm{mdm} 2$ protein expression in 16 cases of nonHodgkin's lymphoma (15 high grade and one 
low grade). This pattern suggests deregulation of the self-regulating feedback loop which is formed by the interaction between $\mathrm{mdm} 2$ and p53 proteins. ${ }^{112}$ Five of these 16 cases were p21 negative high grade non-Hodgkin's lymphomas. In these cases, it is possible that mutations rendering the $\mathrm{p} 53$ gene incapable of activating the mdm 2 and $\mathrm{p} 21 /$ wafl genes might have occurred. In support of these findings, some high grade non-Hodgkin's lymphomas with p53 positive/mdm2 negative protein expression harboured p53 gene mutations $\mathrm{s}^{40}$ and p53 gene mutations were found in $45 \%$ of high grade non-Hodgkin's lymphomas. . $^{3518} 1930$ In this respect, it is worth noting that some of these mutations were found in exons 4 or 10 , outside the classic 'hot spot' regions (exons 5 to 8$).^{5}$ The remaining 11 cases (10 high grade and one low grade) had a p53 positive/mdm2 negative/p21 positive pattern of expression. It is possible that, in these cases, $\mathrm{mdm} 2$ gene deregulation might have occurred in the absence of p53 gene mutation. Alternatively, if the p53 gene is mutated in these cases then p21/waf1 protein expression might have occurred through a p53 independent pathway, as in vitro $\mathrm{p} 21$ expression can be triggered by differentiation inducing agents in p53 negative haemopoietic model systems. ${ }^{33}$ However, data from non-Hodgkin's lymphoma suggest that, at least in these tumours, high concentrations of p21 are associated with wild type p53 gene expression. ${ }^{34} \mathrm{It}$ is of interest that expression of $\mathrm{mdm} 2$ and $\mathrm{p} 21 /$ waf 1 proteins was not found in the absence of $p 53$ protein expression in non-Hodgkin's lymphoma. This is in agreement with the finding that a lack of $\mathrm{p} 53$ protein expression prevents $\mathrm{mdm} 2$ and $\mathrm{p} 21 /$ waf 1 transactivation. ${ }^{671013}$

With regard to the $\mathrm{p} 53$ negative/mdm2 negative/p21 negative non-Hodgkin's lymphomas, it is possible that p53 gene is in the wild type configuration or that the p53 gene is mutated but inactivated because of nonsense or frame-shift mutations. ${ }^{40}$ Moreover, the possibility that some non-Hodgkin's lymphomas with p53 missense point mutations do not exhibit p53 immunostaining may also be considered in view of previous findings in these tumours. ${ }^{5}$ Finally, it is of interest to compare the different patterns of $\mathrm{p} 53 / \mathrm{mdm} 2 / \mathrm{p} 21$ protein expression in non-Hodgkin's lymphoma with the constant $\mathrm{p} 53$ positive/mdm 2 positive/ p21 positive pattern of expression in ReedSternberg cells in all cases of Hodgkin's disease.$^{34}$ Sanchez-Beato et al postulate that the p53 gene in Hodgkin's disease is a tumour suppressor gene and it has been hypothesised that p53 gene mutation could be secondary phenomena in Hodgkin's disease, leading to transformation to a more aggressive variant or anaplastic large cell lymphoma. Taken together, the above data suggest that immunohistological studies on $\mathrm{p} 53, \mathrm{mdm} 2$ and $\mathrm{p} 21 /$ waf 1 protein expression may provide indirect information about the status of the p53 gene in human lymphomas and are a useful adjunct to molecular biology studies.

In summary, our study shows that different patterns of concordant or discordant p53/ $\mathrm{mdm} 2 / \mathrm{p} 21$ protein expression occur in nonHodgkin's lymphoma, suggesting that derangement of the growth suppressive pathway involving these proteins may play a role in the pathogenesis of a proportion of non-Hodgkin's lymphomas. Further studies at the DNA and RNA level are required to gain more insight into this issue.

This work was supported by a grant from the Greek Anticancer Society. We are grateful to the biologist Katerina Darivianaki and technician Elli Karidi for their excellent technical support.

1 Levine A, Momand J, Finlay C. The p53 tumour suppressor gene. Nature 1992:351:453-6.

2 Nigro JM, Baker SJ, Preisinger AC, Jessup JM, Hostetter R Cleary $\mathrm{K}$, et al. Mutations in the $\mathrm{p} 53$ gene occur in diverse human tumour types. Nature 1989;342:705-8.

3 Gaidano G, Ballerini P, Gong JZ, Inghirami G, Neri A Newcomb EW, et al. P53 mutations in human lymphoid malignancies: association with Burkitt lymphoma and chronic lymphocytic leukemia. Proc Natl Acad Sci USA 1991;88:5413-17.

4 Villuendas $R$, Pins MA, Algara $P$, Sanchez-Beato $M$, Sanchez-Verde L, Martinez JC, et al. The expression of p53 protein in non-Hodgkin's lymphomas is not always protein in non-Hodgkin's lymphomas is not always

5 Kocialkowski S, Pezzela F, Morrison H, Jones M, Laha S Harris AL, et al. Mutations in the p53 gene are not limited to classic 'hot spots' and are not predictive of p53 protein to classic 'hot spots' and are not predictive of p53 protein Haematol 1995;89:55-60.

6 Barak Y, Oren M. Enhanced binding of a $95 \mathrm{kd}$ protein to p53 in cells undergoing p53-mediated growth arrest EMBO ₹ 1992;11:2115-21.

7 Momand J, Zambetti GP, Olson DC, George D, Levine AJ. The mdm 2 oncogene product forms a complex with p 53 protein and inhibits p53-mediated transactivation. Cell 1992;69:1237-45.

8 Oliner JD, Pietenpol JA, Thiagalingam S, Gyuris J, Kinzler KW, Vogelstein B. Oncoprotein MDM2 conceals the activation domain of tumour suppressor p53. Nature 1993; activation do

9 Finlay CA. The mdm 2 oncogene can overcome wild-type p53 suppression of transformed cell growth. Mol Cell Biol 1993;13:301-6.

10 Juven T, Barak Y, Zauberman A, George DL, Oren M. Wild type p53 can mediate sequence-specific transactivation of an internal promoter within the $\mathrm{mdm} 2$ gene. Oncogen 1993;8:3411-16.

$11 \mathrm{Wu} \mathrm{X}$, Bayle JH, Olson D, Levine AJ. The p53-mdm2 autoregulatory feedback loop. Genes Dev 1993;7:1126-32.

12 Chen CY, Oliner JD, Zhan O, Fornace AJ Jr, Vogelstein B, Kastan MB. Interactions between p53 and $\mathrm{mdm} 2$ in a mammalian cell cycle checkpoint pathway. Proc Natl Acad Sci USA 1994;91:2684-91.

13 El-Deiry WS, Tokino T, Velculesku VE, Levy DB, Parsons $\mathrm{R}$, Trent JM, et al. Waf1, a potential mediator of p53 tumour suppression. Cell 1993;75:817-25.

14 Harper JW, Adam GY, Wei N, Keyomarsi K, Elledge SJ. The p21 Cdk-interacting protein Cip1 is a potent inhibitor of G1 cyclin-dependent kinase. Cell 1993;75:805-16.

15 Xiong Y, Hannon GJ, Zhang H, Casso D, Kobayashi R, Beach D. P21 is universal inhibitor of cyclin kinase. Nature 1993;366:701-4.

$16 \mathrm{Gu}$ Y, Turk CW, Morgan DO. Inhibition of CDK2 activity in vivo by an associated $20 \mathrm{k}$ regulatory subunit. Nature 1993;366:707-10.

17 Waga S, Hannon GJ, Beach D, Stillman B. The p21 inhibitor of cyclin-dependent kinase controls DNA replication by interaction with PCNA. Nature 1994;369:574-8.

8 Cesarman E, Inghirami G, Chadburn A, Knowles DM High levels of p 53 protein expression do not correlate with p53 gene mutations in anaplastic large cell lymphoma. $A m$ f Pathol 1993;143:845-56.

19 Nakamura H, Said JW, Miller CW, Koeffler HP. Mutation and protein expression of p53 in acquired immunodeficiency syndrome-related lymphomas. Blood 1993; 82:920-6.

20 Martinez JC, Mateo MS, Sanchez-Beato M, Villuendas $R$ Orrade JL, Algara $\mathrm{P}$, et al. MDM2 expression in lymphoid cells and reactive and neoplastic lymphoid tissue. 7 Patho 1995;177:27-35.

21 Cordell JL, Falini B, Erber WN, Ghosh AK, Abdulaziz Z MacDonald S, et al. Immunoenzymatic labelling of monoclonal antibodies using immune complexes of alkaline phosphatase and monoclonal antialkaline phosphatase (APAAP complexes). $\mathcal{f}$ Histochem Cytochem 1984; 32:219-22.

22 Kanavaros P, Kouvidou Ch, Dai Y, Tzardi M, Datseris G, Darivianaki $\mathrm{K}$, et al. MDM2 protein expression in nasopharyngeal carcinomas. Comparative study with p53 protein expression. F Clin Pathol: Mol Pathol 1995;48. protein $322-5$

23 Ladanyi M, Cha C, Lewis R, Jhanwar SC, Huvos AG, Healey JH. MDM2 gene amplification in metastatic osteosarcoma. Cancer Res 1993;53:16-18. 
24 Reiferberger G, Liu L, Ichimura K, Schmidt EE, Collins VP. Amplification and overexpression of the MDM2 gene in a subset of human malignant gliomas without p53 mutasubset of human malignant gliomas

25 Sheikh MS, Shao ZM, Hussain A, Fontana JA. The p53-binding protein MDM2 gene is differentially expressed in human breast carcinoma. Cancer Res 1993;53: 3226-8.

26 Bueso-Ramos CE, Yang Y, de Leon E, McCown P, Stass $\mathrm{SA}$, Albitar $\mathrm{M}$. The human MDM2 oncogene is overexpressed in leukemias. Blood 1993;82:2617-23.

27 Watanabe T, Hotta T, Ichikawa A, Kinoshita T, Nagai H, Uchida T, et al. The MDM2 oncogene overexpression in chronic lymphocytic leukemia and low grade lymphoma of B-cell origin. Blood 1994;9:3158-65.

28 Chilosi M, Doglioni C, Menestrina F, Montagna L, Rigo A Lestani M, et al. Abnormal expression of the p53-binding protein MDM2 in Hodgkin's disease. Blood 1994;84:4295300 .

29 Pezzella F, Morrison H, Jones M, Lane D, Harris AL, Mason DY. Immunohistochemical detection of p53 and bcl-2 proteins in non-Hodgkin's lymphoma. Histopathology 1993;22:39-44.

30 Matsushima AY, Cesarman E, Chadburn A, Knowles DM. Post-thymic T-cell lymphomas frequently overexpress p53 protein but infrequently exhibit gene mutations. $\mathrm{Am} F$ protein but infrequently
Pathol 1994;144:573-84.

31 Villuendas R, Pins MA, Orradre JL, Mollejo M, Algara P, Sanchez $L$, et al. $\mathrm{P} 53$ protein expression in lymphomas and reactive lymphoid tissue. 7 Pathol 1992;166:235-41.

32 Landers JE, Haines DS, Straus JF, George DL. Enhanced translation; a novel model of mdm2 oncogene overexpression identified in human tumour cells. Oncogene 1994;9: 2745-51.

33 Steinman RA, Hoffman B, Iro A, Guillouf C, Liebermann DA, Houseini ME. Induction of p21 (WAF1/CIP1) during differentiation. Oncogene 1994;9:3389-96.

34 Sanchez-Beato M, Pins MA, Martinez-Montero JC, Garcia JF, Villuendas R, Garcia FJ, et al. Mdm2 and p21/waf1, wild type $\mathrm{p} 53$ induced proteins are regularly expressed by weed-Sternberg cells in Hodgkin's disease. $\mathcal{F}$ Pathol (in Reed-Ste
press). 